\title{
Putting "forestry" and "community" into First Nations" resource management
}

\author{
by Annie L. Booth ${ }^{1}$
}

In the last three decades, British Columbia has witnessed an increase in interest on the part of resource-dependent communities in managing local resources to meet their goals and needs. This interest can be found as well amongst First Nation communities. This article explores the idea of community forestry and how it might be incorporated into First Nation forestry initiatives, so that they meet the particular needs of First Nation communities. The article examines definitions of community forestry through an analysis of the idea and practice of community forestry, a discussion of community forestry in a First Nations context, and, finally, through a discussion of a research project examining the link between community and forestry in the Tl'azt'en Nation of north central British Columbia.

While there are different understandings about what community forestry is, two definitions are particularly important in order to understand the link developing between First Nations and forestry initiatives. One definition is structural: community forestry as a form of forest tenure. The second definition is philosophical: community forestry as forestry in which community values and needs are paramount. Both definitions need to be incorporated into First Nations forestry operations to ensure long term success.

\section{What is Community Forestry?}

While the earliest mention of a "community forest" dates back to 1918 (Betts 1995: 23), most of the work on, and broad interest in, the general idea of community forests developed in the 1970 s and 1980 s, through a variety of grassroots initiatives. In British Columbia particularly, interest in involvement in planning forestry operations developed as it became clear that traditional forestry was not addressing community interests. Leases granted to large forestry corporations were neither protecting ecosystems, nor returning much in the way of labour or income to communities adjacent to forest operations. A 1975 study by the Environmental and Land Use Committee Secretariat, and another by the 1976 Royal Commission of Forest Resources confirmed these concerns (Pinkerton 1993).

It was becoming clear that, when not consulted, the public could become vocal in its opposition to "forestry as usual." Out of this situation emerged a number of community-based initiatives, the Slocan Valley Community Management Project being among the first (Taylor and Wilson 1994). Later initiatives included the Tin Wis Coalition (1991) and The Village of Hazelton's Framework on Watershed Stewardship (1991). All of these initiatives argued for a "working forest," but one in which ecosystem values were protected and income and jobs remained in the community. Out of this context also arose increased interest on the part of government to include communities in resource management decisions. This led to initiatives that included the Commission on Resources and Environment (CORE) and the Land and Resources Management Plans (LRMP) process.

\footnotetext{
${ }^{1}$ University of Northern British Columbia, 3333 University Way, Prince George, British Columbia, V2N 4Z9.
}

At the moment, there is a great deal of discussion going on in British Columbia around the concept of community forests. The key to understanding a community forest is the different role for community members. What was emerging from the initiatives outlined above, was a call for increased community participation in forestry, rather than community forestry itself. Community participation does not necessarily challenge conventional forestry practices, but rather includes a variety of methods to give people an opportunity to provide comment on forestry plans. The initiatives noted above, for example, were not proposing community control over forests, but rather advocated public input on decisions made. Community forestry is something different. In community forestry, substantive control and responsibility for forestry operations rests with the community, and most of the benefits remain in the community.

There are currently four community forest prototypes in the British Columbia, each of which fits the emerging definition of "community forest" to greater or lesser degrees. These include the Mission Municipal Forest, the North Cowichan Municipal Forest, the Revelstoke Community Forest, and the Kaslo Community Forest. Mission and North Cowichan date back to the 1930s, Revelstoke was incorporated in 1993, and Kaslo's was granted as of 1997 (its governance has not yet been finalized). A number of other communities are developing proposals for community forests, however a lack of forested land available for new lease arrangements serves as a serious limitation.

The concept of community forestry can be best developed by making reference to the two elements introduced earlier: the structure of the tenure arrangement; and the philosophical underpinnings that lead to community control over management and resource utilization decisions.

Presently, there is no formal "community forest lease" structure in British Columbia. The Mission and Revelstoke forests are Tree Farm Licenses (TFLs) partially situated on crown land, similar to TFLs held by forest companies. While the communities can manage their TFLs to provide broader values, such as recreational trails, or to benefit the community with profit funnelled in to social services, they must meet all governmental regulations concerning TFLs in general (Fletcher and M'Gonigle 1991, Allan and Frank 1994, Revelstoke Community Forest Corp. 1995). Questions have been raised as to how well these forest tenures fit the model of community forestry, since the communities holding these TFLs do not actually have control over the forest, but must live by conditions set by the provincial government, and which have been developed within the context of industrial forestry requirements.

North Cowichan is different, as the forest is ceded municipal land with a fee simple tenure (Fletcher and M'Gonigle 1991). This is closer, perhaps, to the notion of "community" forest. However, the widespread applicability of this model may be limited, as the circumstances leading to this example involved a reversion of private land to the municipality for non-payment of taxes during the 1930s. Such an opportunity may be unlikely 
to happen in other communities today. This is not to say that a "community forest" tenure will not be developed. As more communities undertake to obtain community forest tenures, the provincial government may need to develop the appropriate tenure structure. Sanders (1993) speculates that the greatest challenge to legislators in developing such tenures will be to create tenure systems that can address and respect the wide range of public opinion and expectations surrounding forest management and utilization.

A proposal for a community forest developed by the City of Prince George outlines key elements that might be incorporated by a community forest tenure (Cortex Consultants 1996). Under this proposal, the community would maintain the ability to:

- determine harvesting schedules and location;

- direct timber to local industries;

- levy fees or to issue licenses to harvest timber and non-timber products;

- retain stumpage fees;

- control access; and

- determine landscape issues and all forms of land use.

Such a tenure would provide the community with a facilitating structure under which community values and goals could become the determining factor in setting local forest management policy. However, even in the case where this structural element of community forestry is in place, the second element - that of the community's ability to reflect its values, needs and expectations in terms of forest management policy and practice — needs to be developed.

It is the philosophy behind community forestry which makes it of considerable interest to First Nations as well as to non-native communities. Herb Hammond, a well known proponent of "holistic" forestry, argues that community forestry links a "sense of place" with the responsibility of deciding the future of the forest:

“... without an attachment to 'place,' people frequently rationalize questionable actions on the basis of short-term economic expediency, instead of choosing a conservation approach implied by long-term stewardship" (Hammond 1990).

The focus on forestry as stewardship of a "place" to which forest managers are integrally attached, has obvious appeal for communities with an interest in long term ecological and social stability. From this rationale, the form of community forestry develops.

Duinker et al. (1994) state that the traits that distinguish a community forest are:

- it directly benefits the community;

- the community has the decision-making right and responsibility; and

- the forest is managed for multiple values.

Specifically, a community forest involves the deliberate development of a relationship between a community and its forests, such that all community members have a means of direct involvement in the management of the forests, with a goal of benefiting the whole community (Duinker et al. 1994). To this framework, Witty (1994) adds five additional principles:

- fairness (forestry allocations should build on the region's cultural and natural history);

- integration (the community forest cannot exist in isolation its management must reflect linkages to broader regional and provincial strategies and policy);
- inclusiveness (community forestry management must include all stakeholders and their interests);

- wholeness (the community forest must be managed as a part of a larger ecosystem); and

- governance of diversity (as a significant resource, community forests must be established and managed so that they reflect the diversity of institutional and community interests, without compromising natural and cultural values).

The "who decides, who benefits" focus of community forestry is the key concept that distinguishes it from ordinary commercial forestry. First and foremost, decision-making becomes the right and responsibility of the community, subject, perhaps, to minimum standards set by the province. It is this empowerment to make final decisions that calls into question the descriptions of Revelstoke and Mission as "community forests." In the end both of these models involve compliance with government-set requirements - such as annual harvest levels - even if those requirements significantly interfere with community values and goals.

Community forestry, as briefly outlined above, takes us further afield from commercial forestry than a simple transfer of existing tenures from companies to communities. The philosophical orientation underlying current models of community forestry recognizes the development of long-term relationships between specific communities and the forests in which these communities are situated. This can lead to a significantly different view of people and trees than is provided under the past industrial model of forestry, which tends to view the forest as a resource that can be utilized for the primary benefit of distant communities.

\section{First Nations and Community Forestry}

An examination of First Nations' views of the natural world, and some of the beliefs around appropriate human behaviour with regard to nature, indicates a good fit with the concepts underlying community forestry. This is true both with regard to the philosophy and structure of community forestry, as community forestry may permit not only meeting economic needs for jobs and income, but also offers an opportunity to reconcile traditional values with resource extraction. This is an essential reconciliation today for First Nation communities.

Philosophically, for example, many First Nations would find the assertion by Duinker et al. (1994) of the need for a relationship with nature compatible with traditional values. That relationships are essential between a person and the land is the fundamental basis for Aboriginal peoples' identification of self and culture (Booth and Jacobs 1990). Laguna Pueblo, Paula Gunn Allen (Allen 1979) makes this belief clear:

"We are the land ... More than remembered, the earth is the mind of the people as we are the mind of the earth. The land is not really the place (separate from ourselves) where we act out the drama of our isolated destinies. It is not a means of survival, a setting for our affairs ... It is rather a part of our being, dynamic, significant, real."

Nor is nature simply a biological reality, a part of a purely ecological community. The land gave shape to the people. Cultural attributes such as spirituality, language, rituals, and origin myths are grounded in a particular landscape. As Cherokee, Jimmie Durham testified during the 1970 s US Congressional Hearings on the Tellico Dam construction project: 
"In the language of my people ... there is a word for land: Eloheh. This same word also means history, culture and religion. We cannot separate our place on earth from our lives on the earth nor from our vision nor our meaning as a people ... when we speak of land, we are not speaking of property, territory, or even a piece of ground upon which our houses sit and our crops are grown. We are speaking of something truly sacred." (Matthiessen 1984)

Land, for indigenous peoples, reinforces who they are as humans. This is precisely where a community forest initiative can assist economic development, as it can explicitly incorporate such important traditional values and require that the forestry operation fit the land, rather than fitting the land into an economically driven system of commercial forestry.

First Nation communities also have social and physical characteristics which community forestry can address. Physically, communities are often isolated and face limited opportunities for economic development. For many, forestry is one of few options. As land claims progress in British Columbia, for example, it is likely that many First Nations will acquire full control over some lands and will enter into co-management agreements over other parts of traditional territories. Within this context, the land must serve as an economic resource. However, to respect the social and cultural realities of these First Nations, forestry operations must recognize that the communities remain dependent on that piece of land for all of their future. More difficult, social expectations and needs must be met.

The tight social interrelationships that characterize First Nation communities need to be built into resource management strategies. People are dependent upon each other. In a small community with few economic options, forestry operations will absolutely require community support. Attention to community values thus becomes critically important.

Here, some of the points raised by the community forestry philosophy, outlined earlier, become key. These include, for example, the need to identify and meet community needs, and to integrate the requirements for fairness and inclusiveness into forestry activities. In the absence of such an approach, forestry operations can easily become caught up in community disputes. This is particularly the case when the forest tenure is answerable first and foremost to outside requirements, such as is the case for a TFL, rather than a forest tenure system which is under full community control.

First Nation forestry decision-making can become considerably more complex than in commercial forestry operations, where profit and efficiency are key. For a First Nations community, meeting social needs may be more important than achieving large profits that can be withdrawn from the forestry operation. For example, creating jobs and training opportunities may be considered to be as important as operational efficiency. Other important activities that can be affected by harvesting operations must be taken into account, including subsistence fishing, trapping, medicinal plant collection, berry picking, and hunting. Community forestry permits decision-making calculations that balance fiscal bottom-line considerations with social, cultural and other objectives related to the forest.

The importance and suitability of community forestry development among First Nations are confirmed by the activities of the National Aboriginal Forestry Association (NAFA). In its Aboriginal Forestry Land Management Guidelines, the importance of involving the community is stressed:
"Community members must be involved at each step to direct forest care. Communal awareness, wisdom and accountability in forest land management will help build heathy and sustainable forests... Community involvement should build understanding and commitment. Community members' knowledge and experience, with the assistance of professionals, can be used to define issues, develop common beliefs, articulate a vision and develop plans for forest management activities." (NAFA 1995)

There are at least two challenges that arise from this discussion. The first is the more difficult, and involves reconciling traditional values with the requirements of non-traditional resource extraction activities geared toward meeting economic objectives. The second challenge, stemming from the first, is to successfully build mechanisms that provide for substantive community involvement in forestry decision-making.

Traditional values are based on a complexity of factors emerging from the specific history and culture of the community. It is, perhaps, impossible to fully reconcile traditional values with the requirements of commercial harvesting. Nonetheless, while traditional values are important, so too is the task of creating economic stability for what are typically rapidly growing populations. Thus, many First Nations are realizing that they must reach some accommodation between these competing needs. This accommodation is not always easy, as commercial resource development cannot be wholly controlled by the community, but must fit within the broader requirements of the increasingly global, modern capitalist structure.

\section{The Menominee Community Forestry Experience}

A good example of a First Nation that appears to have been successful at reconciling traditional values with economic need can be found in the Menominee of central Wisconsin. This community has managed its communityowned forest for the past 150 years in a manner that both meets community needs for access to game, fish and medicinal plants, while providing jobs and capital to invest in community infrastructure development.

From the beginning of a local forestry operation in 1854, the goal of tribal leaders was to maintain a steady harvest of wood through selective harvesting. This circumstance did not change in 1890 when the tribe received government permission to expand its forestry operation into a commercial venture through the establishment of a sawmill. Over the past 150 years, the Menominee forest has supplied over 2 billion board feet of timber (Huff and Pecore 1995). Several important factors have contributed to this success. First, the Menominee, unlike many Aboriginal nations in the United States, were never removed from their traditional lands and were able to prevent the extensive clearcut activities that went on in the rest of Wisconsin in the 1840 s and 1850 s. The Menominee reserve today encompasses an area of over 100,000 ha. The tribe benefited as well from a state law authorizing them to develop commercial forestry operations, as most tribes at the time were forbidden to undertake commercial activity. A third factor was a progressive and aggressive chief and tribal council who were able to successfully negotiate with the United States federal government for a commercial mill. Finally, unlike other tribes in the late $1880 \mathrm{~s}$, the Menominee refused to engage in the Allotment 
Act of 1887 . This Act would have given individual members of the nation private property rights over reservation lands, a situation which, in other regions of the US, led to subsequent sales to non-Indians and, ultimately, to division of Indian lands. The Menominee stress that keeping land as a collective property was what permitted a successful forestry program (Pecore 1992).

Under the Menominee community forest management structure, decisions about forest operations are made by a board that is directly answerable to community members. As the operation managers report:

"The success of the forest enterprise on the Menominee

Reservation is rooted in the community. The tribal members maintain the enterprise through their support of the harvest methods and their refusal to allow their forest to be degraded. To develop a market-oriented forestry enterprise that is ecologically and socially sustainable as well as economically feasible requires a society that is well balanced with respect to these areas." (Huff and Pecore 1995: 18)

As one elder observed, "Everything we have comes from Mother Earth, from the air we breathe to the food we eat - and we need to honour her for that. In treating the forest well, we honour Mother Earth" (Huff and Pecore 1995).

According to the earlier discussion of community forestry, the Menominee tribal forestry operation appears to fit the definition of "community forest". It is structured to be managed by people directly answerable to the tribe, and it appears to be based upon the Menominee world view and the close relationship between people and the land. The Menominee forest is thus able to meet community values and goals, particularly traditional values, and returns benefits directly back to the community, largely through jobs. Further, the forest has remained productive and has been successfully managed for other non-timber products such as game animals and medicinal plants. The Menominee's practice of sustainable forestry has relied upon intensive management regimes, a community willingness to accept benefits limited to what the forest can provide on a sustainable basis, and has benefited from the availability of high value species.

Nonetheless, the Menominee forest is experiencing significant pressures. Originally comprised primarily of white pine, the forest profile is changing, with less valuable species becoming dominant. Further, while jobs are a direct benefit to the community, profits are small and must be invested back into the mill in order to remain commercially viable. At the same time the tribal leadership is facing internal demands for greater affluence. Finally, other priorities may need to be dealt with at the expense of the forest. For example, expansion of the town sites to accommodate population growth and returning tribal members leads to development incursions into the forest (Huff and Pecore 1995).

It remains to be seen if the Menominee will remain as a prototype of successful community forestry into the next century. Nonetheless, this case does serve to illustrate the key principle that "the success of the forest enterprise is rooted in the community."

\section{The Tl'azt'en Nation Community Forestry Research Project ${ }^{2}$}

Within the community forestry paradigm, resource management decisions must take into account the complex relationships between people and the land. They must, therefore, be community decisions that reflect community values. As a result, all sectors of the community need to be involved - spiritual and secular leaders, elders and children, wage earners and those outside the formal wage economy, and so on. If the first challenge of community forestry relates to reconciling traditional values with the requirements of non-traditional resource extraction activities, this need for broad-based community participation constitutes the second major challenge: how can the "community" be brought into "community forestry."

These two challenges are the focus of a collaborative project between the University of Northern British Columbia and the Tl'azt'en Nation, located in the north-central region of the province. Funded by Forest Renewal British Columbia, the project is designed to examine community participation in the context of a unique, long-standing forestry operation. The project aims to assist the Tl'azt'en to better plan for future development of forest resources on traditional lands, and to develop strategies which address the cultural as well as the economic needs of the community. In addition to reviewing and documenting past experiences and exploring future directions in forestry, the project will integrate the Tl'azt'en Nation's experience in forest management into the development of materials for use by other First Nations interested in community-based forestry programs.

The Tl'azt'en Nation became an early participant in community-based forestry through a unique set of circumstances. After resorting to roadblocks in 1980 to protest BC Railway's taking easements from Tl'azt'en land, the Tl'azt'enne were encouraged to begin a forestry enterprise. Subsequently, they successfully bid for a Tree Farm License (TFL 42), and are today the only First Nation in British Columbia to hold a TFL. It appears that the bid for the TFL resulted from a very high level of support from within the community, reflecting both a desire to gain control over their future, as well as for the more tangible rewards of jobs and training. The Nation was also successful in obtaining the go-ahead to build a sawmill to process the timber coming out of the TFL. By 1992 both TFL and sawmill were online. Tanizul Timber is the company that manages TFL 42, and Teeslee Forest Products operates the mill.

The Tl'azt'en have attempted to meet community goals and aspirations for forestry operations while, at the same time, answering to external forces. Tanizul Timber and Teeslee Forest Products, although managed by band members, must both answer to external factors such as market fluctuations, pressures for investment and revenue generation, and the visions of non-Aboriginal business partners. In addition they must meet all the requirements placed upon TFLs, including meeting the harvest levels set by their Annual Allowable Cut. This latter constraint means that forestry operations are often inflexible with regard to meeting community goals and values.

To ensure continued support from the community, the diversity of Tl'azt'enne goals, and the values underpinning them, must somehow be incorporated into the forestry operations. Community goals and expectations for TFL 42's operation have evolved since the beginning of forestry operations, and tension
Cresearchers from the Tl'azt'en Nation are Beverly Bird (Research Coordinator), Umit Kazithan (General Manager), and Cheryl Pierre (Research Annie Booth (Environmental Studies Program), Gail Fondahl (Geography Program), and Christine Callihoo and Phil Morris (Research Assistants). 
between community members and the board members of Tanizul Timber and Teeslee Forest Products has increasingly emerged. The recent slump in Asian markets has put further pressure on these companies. Arising out of this context, in late 1997, Teeslee ceased operations pending a re-assessment of forestry operations.

It is within this context that the UNBC-Tl'azt'en research project will examine two key issues. The first relates to identifying the goals and expectations of community members regarding the management and utilization of TFL 42 , while the second involves assessing the extent to which these goals and expectations correspond to those of the board and managers of Tanizul Timber and Teeslee Forest Products. In particular, the project will assess the extent to which traditional Tl'azt'en values have been - or might be - reconciled with a those of a commercial forestry operation.

To achieve these research goals, an assessment of traditional values is currently being carried out, along with an assessment of how, and the extent to which, these values can be reflected within commercial forestry operations. This will assist in identifying the key conditions that need to be established for a successful community-supported forestry operation. Interviews are being conducted with a broad spectrum of the community, including: the Chief and Band Council members; elders; "keyoh" holders (individuals with rights and responsibilities regarding traditional territories); board members, managers, and employees (past and present) of the two forest companies; and, young people interested in working in resource management and commercial development.

The project will also document the start-up of the TI UNBC Research Forest, a co-managed forest established in 1997 on Tl'azt'en lands. Talking to people involved with the establishment of this research forest will provide a unique perspective on the negotiations and community goals that led to the project. Community-based research will permit an assessment of the expectations held by various community sectors for the Research Forest, and, more interestingly, differences, if any, between community perceptions of the TFL and the Research Forest. This research should lead to findings that will be useful in evaluating alternative co-management strategies.

Although community research is still underway, some preliminary findings may provide a sense of what the project hopes to accomplish through studying the links between forestry management and the community. Initial interviews with key Tl'azt'en community members indicate that there is not only a deep concern over protecting traditional values, but an awareness that the reconciliation between values and economies may never be resolved. While the community seems to have been deeply involved in the TFL bidding process in the beginning, this participation has dropped off over time. There are perceptions amongst some community members that the restrictive TFL structure has hindered the development of "true" community forestry by limiting the scope of decision-making available to the community. Recognition of this factor by the Tl'azt'en leadership is indicated in the Nation's decision to apply for a "community forest" tenure, much as other communities are doing.

There are several related areas that will emerge from this research project. A history of the establishment of TFL 42, and the social, economic and political forces that formed the context in which this could occur, is developing out of the interviews with
Tl'azt'enne who were involved in the events surrounding the acquisition of the TFL. A key product of this research project will be the compilation of "lessons learned" from the Tl'azt'en experience that may be of use to other First Nations in their assessment of the opportunities and challenges of developing community forest-based resource development. A significant extension activity will include the development of a manual and video on First Nation's involvement in community-based forestry, drawing upon the Tl'azt'en experience. The manual will include information on different models of community forestry, on-going forestry operations amongst other First Nations, and a guide to assessing the advantages and disadvantages inherent in these models.

A key product will be the collection of data that can be used to assist the Tl'azt'en leadership as they address internal and external challenges in their forestry initiatives. In particular, it is hoped that this research will help to bring community members back on-side in order to provide support for community forestry operations. The limitations of the present tenure structure - that of the TFL - are recognized. It is possible that other tenure structures, such as the research forest or the proposed community forest, will meet the Tl'azt'en's needs more fully. However, even in the absence of changes to the tenure system, it is anticipated that the research findings will assist in bringing the $\mathrm{Tl}$ 'azt'en values and perspectives more fully into their forestry initiatives.

Most significantly perhaps, the research is expected to lead to the development of insights that will provide assistance in developing new structures for community forestry. Insofar as possible, these structures will be designed to integrate community values and community participation into forestry operations, and provide the context in which traditional and non-traditional values, goals, and expectations in a First Nation community can be identified, assessed and articulated.

\section{Conclusion}

Much has been written that suggests, in passing, the utility of including the community in resource development activities. The strategies that can be used to accomplish this, however, are less often outlined. The issue is, nonetheless, increasingly important as First Nations move towards self-government and self-management of resources. Given the particular nature and needs of First Nation communities, there are two challenges that must be met: reconciling traditional values with non-traditional resource extraction for economic gain; and putting the community into forestry. While the challenge is complex, the Tl'azt'en Nation may soon provide valuable insights into how community forestry might be achieved in a First Nation context.

\section{References}

Allen, P.G. 1979. Iyani: it goes this way. In Hobson, G. (ed.). The Remembered Earth. pp. 191-193. Red Earth Press, Alburquerque, NM. Allan, K. and D. Frank. 1994. Community forests in British Columbia: Models that work. Forestry Chronicle 70(6): 721-724. Betts, M. 1995. An analysis of the potential for community forestry in New Brunswick. Unpublished MA Thesis, University of New Brunswick, Fredericton, New Brunswick.

Booth, A.L. and H.M. Jacobs. 1990. Ties that bind: Native American beliefs as a foundation for environmental consciousness. Environmental Ethics 12(1): 27-43.

Cortex Consultants Inc. 1996. Feasibility study: Prince George Community Forest. 
Duinker, P.N., P.W. Matakala, F. Chege and L. Bouthillier. 1994. Community forests in Canada: An overview. Forestry Chronicle 70(6): $711-720$.

Fletcher, C. and M. M'Gonigle. 1991. The forces of governance, and the limits of law: Community involvement in forest planning. Forest Planning Canada 7(3): 24-31.

Hammond, H. 1990. Community Control of Forests. Forest Planning Canada 6(6): 43-45.

Huff, P.R. and M. Pecore. 1995. Case study: Menominee Tribal Enterprises (Menominee Reservation, Wisconsin, USA). Madison, WI: Institute for Environmental Studies and the Land Tenure Centre, University of Wisconsin-Madison.

Matthiessen, P. 1984. Native earth. Parabola 6(1): 6-17.

NAFA. 1995. Aboriginal forest land management guidelines: A community approach. National Aboriginal Forestry Association. Ottawa, ON.
Pecore, M. 1992. Menominee sustained-yield management: A successful land ethic in practice. Journal of Forestry 90(7): 12-16.

Pinkerton, E. 1993. Co-management efforts as social movements. Alternatives 19(3): 33-38.

Revelstoke Community Forest Corporation. 1995. A historical perspective. City of Revelstoke, BC.

Sanders, P.R.W. 1993. Community forests in British Columbia, Canada: An overview of the current status. University of British Columbia Malcolm Knapp Research Forest, Maple Ridge, BC.

Taylor, D. and J. Wilson. 1994. Ending the watershed battles: BC forest communities seek peace through local control. Environments 22(3): $93-102$.

Witty, D. 1994. Community forests and community development: An emerging alternative. pp. 27-31. In Proc. Community Forests Workshop. Mitchell-Banks, P. (ed.). March 25-26, 1994. Maple Ridge, BC. 